\title{
Article \\ Protective Effect of Resveratrol against Hepatotoxicity of Cadmium in Male Rats: Antioxidant and Histopathological Approaches
}

\author{
Najah M. Al-Baqami ${ }^{1, *}$ and Reham Z. Hamza ${ }^{2}$ (D) \\ 1 Department of Biological Sciences, Zoology, King Abdul-Aziz University, Jeddah 21589, Saudi Arabia \\ 2 Biology Department, Main Campus, College of Science, Taif University, Taif 21944, Saudi Arabia; \\ Reham.z@tu.edu.sa \\ * Correspondence: nalbogami@Kau.edu.sa
}

Citation: Al-Baqami, N.M.; Hamza, R.Z. Protective Effect of Resveratrol against Hepatotoxicity of Cadmium in Male Rats: Antioxidant and Histopathological Approaches. Coatings 2021, 11, 594. https:// doi.org/10.3390/coatings11050594

Academic Editor: El-Sayed Abd El-Aziz

Received: 16 March 2021

Accepted: 8 May 2021

Published: 18 May 2021

Publisher's Note: MDPI stays neutral with regard to jurisdictional claims in published maps and institutional affiliations.

Copyright: (c) 2021 by the authors. Licensee MDPI, Basel, Switzerland. This article is an open access article distributed under the terms and conditions of the Creative Commons Attribution (CC BY) license (https:/ / creativecommons.org/licenses/by/ $4.0 /)$.

\begin{abstract}
Cadmium (Cd) is widely used in some industries and emitted from fossil fuels. It is a heavy metal with a number of side effects, including hepatotoxicity. Resveratrol (Rs) is considered an important polyphenol, which is a secondary plant metabolite and has the ability to scavenge free radicals. The study was designed to evaluate the effects of resveratrol on $\mathrm{Cd}$, which induced hepatotoxicity, by the assessment of some histopathological and biochemical alterations. Forty male albino rats were divided into four groups: the 1st group was the control group, the 2nd group was treated with $\mathrm{Cd}(5 \mathrm{mg} / \mathrm{kg})$, the 3rd group was given $\mathrm{Rs}(20 \mathrm{mg} / \mathrm{kg})$, and the 4 th group was treated with $\mathrm{Cd}$ in combination with Rs intraperitoneally for 30 successive days. The results indicate that $\mathrm{Cd}$ increased liver enzymes alanine aminotransferase and aspartate aminotransferase (AST and ALT), alkaline phosphatase ALP and gamma-glutamyl transferase $(\gamma-\mathrm{GT})$ while reducing the total protein level; Cd increased the malondialdhyde (MDA) level while decreasing the levels of other antioxidant enzymes super oxide dismutase, catalase and glutathione peroxidase (SOD, CAT and GPx). Serious congestion and hemorrhage related to the hepatic tissues were noticed in the Cd group, and Rs plays a major role in alleviating histopathological injuries and hepatic oxidative damage. It is clear that Rs has the ability to minimize the hepatotoxicity induced by $\mathrm{Cd}$ in male rats.
\end{abstract}

Keywords: cadmium; resveratrol; liver; oxidative stress; pollution; histopathology

\section{Introduction}

The heavy metals toxicity is a universal problem for all livings. Toxicity of the heavy metals depends mainly on many factors, mainly the exposure route and nutrition. These industrial impacts have resulted in increasing environmental pollution and the production of free radicals and reactive oxygen species, such as cadmium (Cd) [1].

$\mathrm{Cd}$ is a highly common environmental pollutant and it is emitted into the atmosphere and aquatic environment, this heavy metal toxicity has increased dramatically during the 20th century [2]. The wide environmental distribution of $\mathrm{Cd}$ leads to elevated interest in its high toxicity and its harmful environmental effects [3]. Cd accumulates excessively in the hepatic and renal tissues and can cause severe cellular damages in different organs [4].

Cadmium is a toxic heavy metal which is commonly used in the industrial paints, electroplating, manufacturing of a wide range of batteries and the agricultural industry. In addition to its high used industrial applications, $\mathrm{Cd}$ is also found in soil, water, vegetables, aquatic foods and industrial workplaces [5]. Cigarette smoke is of the most public origin of $\mathrm{Cd}$. Therefore, there is a high risk of possible exposure to $\mathrm{Cd}$. Release of $\mathrm{Cd}$ into the environment resulting from its use poses a potential danger to the general population and represents major health hazards. Exposure to $\mathrm{Cd}$ has harmful effects on the cells and tissues in a variety of organs, including the hepatic tissues [5]. 
When high amounts of $\mathrm{Cd}$ accumulate in the hepatic and renal tissues and exceed the binding limit, the compound-bound $\mathrm{Cd}$ ions are believed to cause high toxicity in the liver and kidney tissues of the body [5].

$\mathrm{Cd}$, which is considered as one of the toxic heavy metals, poses several dangers to both animals and human health. Nearly 13,000 tons of Cd is produced each year, mainly from batteries, a lot of alloys, coatings and chemical stabilizers [6].

Cd-induced high oxidative damage leads to DNA genotoxicity and high lipid peroxidation. Several studies have demonstrated a positive relationship between induction of high lipid peroxidation and exposure to Cd [7].

Scientific studies have proven that excessive use of antioxidants is of high importance to our bodies. These substances interact, scavenge and stabilize the free radicals and, thus, prevent all cellular damage caused by oxygen species and free radicals [7].

$\mathrm{CdCl}_{2}$ administration to animals induced hepatic lipid peroxidation, decreased Glutathione (GSH) content (to 65\%) and inhibited catalase (CAT) (to 68\%) and Glutathione peroxidase (GPx) (to 60\%) in the hepatic tissues. Resveratrol prevented Cd-induced lipid peroxidation and $\mathrm{Cd}$-induced inhibition of hepatic antioxidant enzymes. Rs were effective against Cd-induced hepatotoxicity and oxidative stress [8].

Resveratrol is obtained from the roots of the Polygonum cuspidatum plant used for the treatment of skin diseases, cardiovascular diseases and hepatic diseases. Rs is a phenolic phytocompound $[9,10]$ found in grapes and cranberries. It is a potent antioxidant and it has been demonstrated in the brain [10] and the liver [11].

Resveratrol is a free radical scavenger that elevates the activity of several antioxidant enzymes, such as superoxide dismutase, catalase and glutathione [12].

Resveratrol can be obtained from natural foods such as fruits, juices and vegetables [13]. Recently, resveratrol, as well as bioactive compounds, have been recommended as dietary supplements due to their positive health effects [14].

Resveratrol is showing promising results due to its hepatoprotective therapeutic characteristics and its antioxidant activities in alleviating hepatotoxicity [15]. Sener et al. [16] demonstrated that Rs has a potent hepatoprotective effect against paracetamol in male mice due to its ability inhibit cytokines, decrease oxidative stress and high lipid peroxidation $[16,17]$. Resveratrol has resulted in vasodilation, so Rs mainly causes a lowering high blood pressure [18].

With regards to the effects of resveratrol in metal toxicity, only the influence of resveratrol on heavy metals induced oxidative DNA injury was studied in cell cultures. Resveratrol which is a naturally occurring polyphenol found in the skin of grapes, has been reported to exert protective effects in cancer, possibly due to antioxidant properties [10].

Additionally, resveratrol can enhance the production of cellular antioxidant enzymes in heart tissues and vascular cells, which leads to a decline in oxidative damage markers [19]. Resveratrol displays anti-aging activity, and this compound is useful in the treatment of highly neurodegenerative disorders.

Resveratrol is a polyphenolic compound, which mainly exists in grapes. It has antioxidant capacities and hepatoprotective effects [20].

Several previous studies have explored the protective effects of Rs against oxidative injury [21].

Resveratrol provides hepatoprotective effects against hepatoxicity induced by many toxicants, such as carbon tetrachloride [22].

Most toxicants cause hepatic injury. Therefore, the current study aimed to evaluate the possible protection and antioxidant capacities of Rs against Cd hepatotoxicity; this aim was achieved through biochemical, histological level and antioxidant enzyme analyses of the liver. 


\section{Materials and Methods}

\subsection{Chemicals}

$\mathrm{CdCl}_{2}$ was used at a dose of $5 \mathrm{mg} / \mathrm{kg}$, which is equal to the lethal dose (LD) $)_{50}$ [23]. All the used chemicals were stored at temp. $2-8{ }^{\circ} \mathrm{C}$. Cd was purchased from Sigma-Aldrich. Resveratrol was obtained from a Chinese company (Xi'an Natural Field Bio-Technique Co., Xi'an, China) for chemicals under code number 430075000.

\subsection{Animals}

Forty male albino Wistar rats, weighing about 150-160 g, were obtained from the king Fahad center at King Abdul-Aziz University, Jeddah, Saudi Arabia. Animals were adapted for two weeks before experimentation and provided with food and water; following the National Institutes of Health Guidelines for care and use. The experiment was carried out according to ethical committee approval in deanship of scientific research at the Taif University under approval number: 39-31-0034.

\subsection{Experimental Design}

The Cd and Rs doses were estimated according to Renugadevi and Prabu [23] and Oktem et al. [24]. About 40 male rats were split into 4 groups, 10 rats in each group as follows: Treatment with the tested compounds intraperitoneally (i.p) on one $\left(\mathrm{CdCl}_{2}\right.$ was firstly injected and after $10 \mathrm{~min}$ Rs was injected in another place of 1st injection) for 4 weeks was: the 1 st group served as the control group and was administrated normal physiological saline; the 2nd group was treated with $\mathrm{CdCl}_{2}(5 \mathrm{mg} / \mathrm{kg})$, with concentration $\left(1 \times 10^{-3} \mathrm{~mol} / \mathrm{L}\right)$; and the 3rd group was treated with Rs at a dose of $20 \mathrm{mg} / \mathrm{kg}$, Concentration of Rs was calculated as follows: $\left(20 \times 10^{-3}\right) \mathrm{g}$ of Rs was dissolved in $100 \mathrm{~mL}$ saline, with concentration $\left(1 \times 10^{-3}\right)$. Finally, the 4 th group was treated with $\mathrm{CdCl}_{2}$ plus $\mathrm{Rs}$. Treatment for all groups was intraperitoneally for 30 successive days as shown in the experimental protocol (Figure 1).

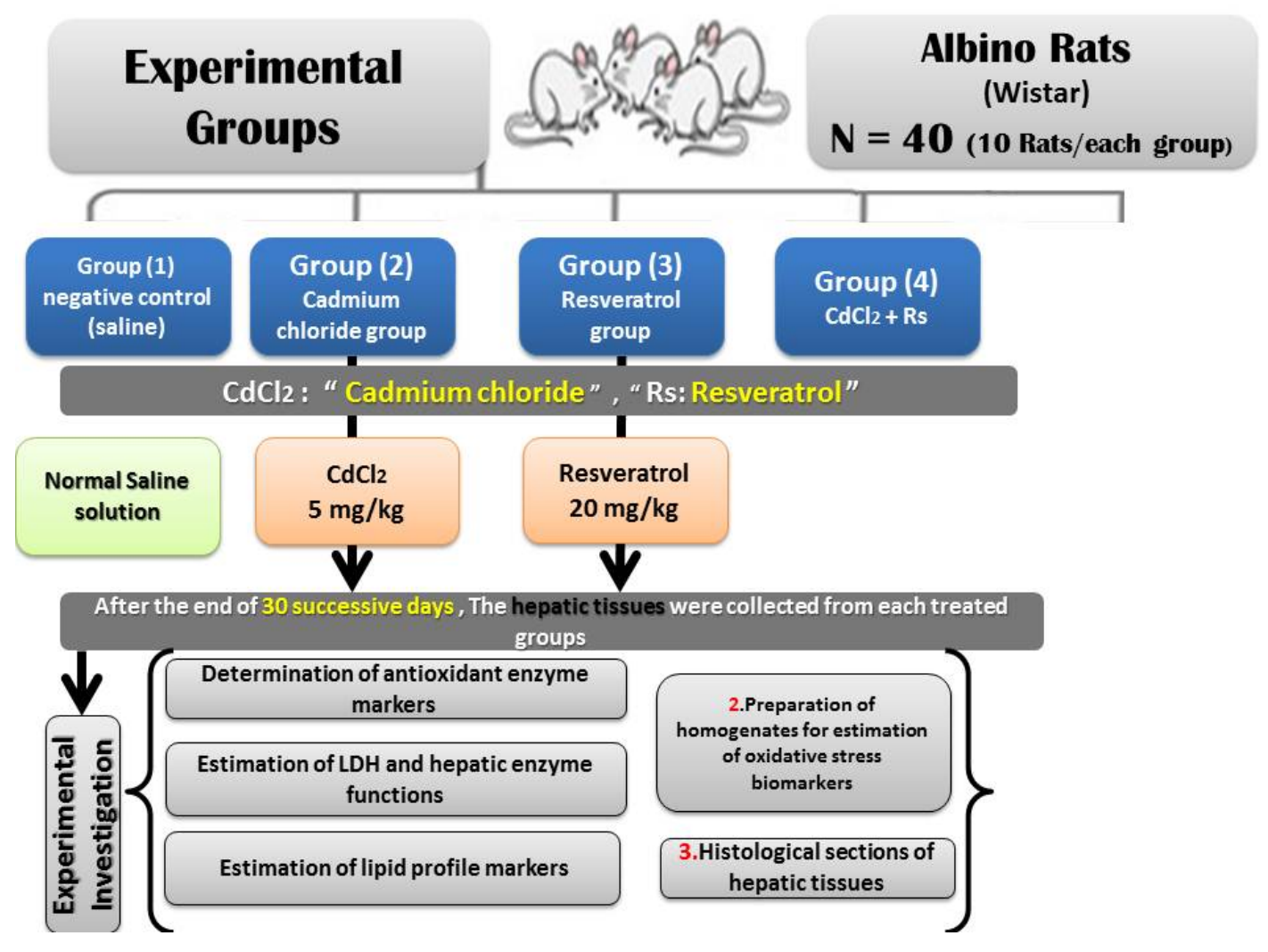

Figure 1. Graphical of experimental protocol. 


\subsection{Blood Samples Collection}

Blood samples were harvested from the retro-orbital plexus according to Boussarie [25], and then the serum was used for biochemical analyses.

\subsection{Biomarkers of Hepatic Functions}

Lactic dehydrogenase (LDH) activity was determined by Human kits. Activities of ALT and AST were determined according to Reitman and Frankel [26]. ALP and $\gamma$-GT activities were estimated according to Young et al. [27] and Orlowski and Meister [28]. Albumin and total protein levels were evaluated according to Bowers and Wong [29] and Bradford [30], respectively.

Cholesterol and triglycerides levels were determined according to Carr et al. [31]. HDL-c and LDL-c were obtained by the method of Warnick et al. [32]. However, VLDL-c levels were determined according to Friedewald [33].

\subsection{Tissue Preparation}

Hepatic tissues ( $\sim 0.35 \mathrm{~g})$ were used for the analysis of oxidative stress parameters. Hepatic tissues were immersed and homogenized with a $50 \mathrm{mM}$ ice-cold phosphate buffer ( $\mathrm{pH}$ 7.4). The resulting supernatant was used for the assessment of antioxidant enzymes.

\subsection{Determination of Antioxidant Markers}

Lipid peroxidation was estimated according to Esterbauer and Cheeseman [20]. Superoxide dismutase (SOD) activity was measured according to Marklund and Marklund [34] by using Human kits (Germany). Catalase (CAT) activity was measured according to Aebi [27]. CAT activity was measured in tissues by assaying the hydrolysis of $\mathrm{H}_{2} \mathrm{O}_{2}$ and the resulting decrease in absorbance at $240 \mathrm{~nm}$ over a $3 \mathrm{~min}$ period at $25^{\circ} \mathrm{C}$, it was evaluated according to Aebi by using Human kits (Germany) [35]. Glutathione peroxidase (GPx) was determined according to Hafeman et al. [36] GPx activity was determined in the liver tissues. The peroxide substrate $(\mathrm{ROOH})$ and total antioxidant capacity was determined according to Prieto et al. [37].

\subsection{Histological Evaluation}

Parts of the liver tissues were fixed in $10 \%$ neutral buffered formalin, and other processing was performed as described by Gabe [38]. Liver tissues were fixed in 10\% formalin, and then it was removed by washing the samples with tap water overnight. The tissues were dehydrated using a series of alcohols and were embedded in paraffin. Sections were cut using a microtome at $5 \mu \mathrm{m}$ thickness. The thin sections were stained with hematoxylin and eosin. The slides were examined by light microscope and photographed by digital camera.

\subsection{Statistical Analysis}

The collected data was entered into and analyzed by computer using Statistical Package of Social Services (Chicago, IL, USA), version 25 (SPSS) (IBM, 2017) and Open Epi version 2.3.1 (Dean et al., 2013). A Shapiro-Wilk test was used to determine the distribution characteristics of variables and variance homogeneity. Data were summarized as mean and standard deviation. One way analysis of variance (ANOVA) and post hoc (LSD) were used to test differences between groups. Variances of $p$-value $<0.05$ were taken as significant [39].

\section{Results}

In Table 1, ALT, AST, ALP, LDH and $\gamma$-GT were markedly elevated in the Cd group with a significant decline in total protein levels. Treatment with Rs afforded non-significant alterations in ALT, AST, ALP, LDH, $\gamma$-GT and total protein levels compared to the control group. All liver parameters declined significantly in the hepatic tissues of the $\mathrm{Cd} / \mathrm{Rs}$ group as compared to the Cd group in ALT, AST, LDH, ALP and $\gamma$-GT, respectively. 
Table 1. Effect of either cadmium, resveratrol, or both, on some liver functions in male rats.

\begin{tabular}{|c|c|c|c|c|c|c|}
\hline Groups & $\begin{array}{l}\text { Total Protein } \\
\quad(g / d L)\end{array}$ & $\begin{array}{l}\text { LDH } \\
(\mathrm{U} / \mathrm{L})\end{array}$ & $\begin{array}{c}\mathrm{AST} \\
(\mathrm{U} / \mathrm{mL})\end{array}$ & $\begin{array}{c}\mathrm{ALT} \\
(\mathrm{U} / \mathrm{mL})\end{array}$ & $\begin{array}{l}\gamma \text {-GT } \\
(\mathrm{U} / \mathrm{L})\end{array}$ & $\begin{array}{l}\text { ALP } \\
(\mathrm{U} / \mathrm{L})\end{array}$ \\
\hline 1 -Control group & $8.19 \pm 0.78$ & $115.25 \pm 2.02$ & $13.11 \pm 1.01$ & $12.36 \pm 0.78$ & $3.21 \pm 0.25$ & $10.12 \pm 1.14$ \\
\hline 2-Cd group & $3.48 \pm 0.59^{a, b}$ & $861.36 \pm 1.25^{a, b}$ & $152.36 \pm 2.54^{\mathrm{a}, \mathrm{b}}$ & $172.71 \pm 2.31^{\mathrm{a}, \mathrm{b}}$ & $7.65 \pm 1.15^{a, b}$ & $68.32 \pm 2.55^{a, b}$ \\
\hline 3-Rs group & $7.14 \pm 1.15$ & $110.25 \pm 1.05$ & $13.28 \pm 1.72$ & $12.83 \pm 1.24$ & $3.41 \pm 0.37$ & $9.98 \pm 1.22$ \\
\hline $4-\mathrm{Cd}+\mathrm{Rs}$ group & $5.18 \pm 1.49$ & $146.25 \pm 1.75$ & $43.12 \pm 2.02$ & $33.48 \pm 2.11$ & $3.87 \pm 0.28$ & $13.36 \pm 1.27$ \\
\hline \multicolumn{7}{|c|}{ Post hoc $p$-value } \\
\hline Control vs. $\mathrm{CdCl}_{2}$ & $<0.001$ * & $<0.001 *$ & $<0.001 *$ & $<0.001 *$ & $<0.001 *$ & $<0.001 *$ \\
\hline Control vs. Rs & 0.44 & 0.11 & 0.32 & 0.79 & 0.34 & 0.42 \\
\hline $\begin{array}{c}\text { Control vs. } \mathrm{CdCl}_{2}+ \\
\text { Rs }\end{array}$ & 0.38 & $<0.001 *$ & $<0.001 *$ & $<0.001$ * & 0.30 & $<0.001 *$ \\
\hline $\mathrm{CdCl}_{2}$ vs. Rs & $<0.001$ * & $<0.001 *$ & $<0.001 *$ & $<0.001$ * & $<0.001$ * & $<0.001 *$ \\
\hline $\begin{array}{l}\mathrm{CdCl}_{2} \text { vs. } \mathrm{CdCl}_{2}+ \\
\text { Rs }\end{array}$ & $<0.001$ * & $<0.001$ * & $<0.001 *$ & $<0.001 *$ & $<0.001$ * & $<0.001$ * \\
\hline Rs vs. $\mathrm{CdCl}_{2}+\mathrm{Rs}$ & 0.10 & $<0.001 *$ & $<0.001$ * & $<0.001$ * & 0.10 & $<0.001$ * \\
\hline
\end{tabular}

* Statistically significant ( $p$-value < 0.05). Cd: cadmium; Rs: resveratrol; ALT: alanine aminotransferase; AST: aspartate aminotransferase; ALP: alkaline phosphatase; LDH: lactate dehydrogenase; and $\gamma$-GT: gamma glutamyl transferase. ${ }^{a}$ : significant difference to control group; b: significant difference to Rs group.

The antioxidant enzymes (SOD, GPx and CAT) declined significantly after Cd treatment (Table 2). The administration of Rs to the Cd-group restored these antioxidant enzymes when compared to the Cd-alone group. The Cd-treated group showed decreased SOD activity, which was elevated when the DC group was treated with Rs. CAT activity was decreased significantly in the hepatic tissues of the $\mathrm{Cd}$ group as compared to the control group (Table 2).

Table 2. Effect of either cadmium, resveratrol, or both, on some antioxidant/oxidative stress parameters in livers of male rats.

\begin{tabular}{|c|c|c|c|c|c|}
\hline Groups & $\begin{array}{c}\text { MDA } \\
\text { (nmol/g Tissue) }\end{array}$ & $\begin{array}{c}\text { GPx } \\
\text { (mg/g Tissue) }\end{array}$ & $\begin{array}{c}\text { CAT } \\
\text { (U/g Tissue) }\end{array}$ & TAC $\%$ & $\begin{array}{c}\text { SOD } \\
\text { (U/g Tissue) }\end{array}$ \\
\hline Control group & $5.02 \pm 1.01$ & $16.15 \pm 1.69$ & $10.43 \pm 1.58$ & $96.8 \%$ & $14.12 \pm 1.23$ \\
\hline $\mathrm{CdCl}_{2}$ group & $115.28 \pm 1.21^{\mathrm{a}, \mathrm{b}}$ & $6.55 \pm 1.19^{a, b}$ & $1.51 \pm 0.36^{\mathrm{a}, \mathrm{b}}$ & $77 \%$ a,b & $3.26 \pm 0.66^{a, b}$ \\
\hline Rs group & $5.01 \pm 0.89$ & $17.25 \pm 1.29$ & $10.41 \pm 1.22$ & $98 \%$ & $14.15 \pm 1.15$ \\
\hline $\mathrm{CdCl}_{2}+$ Rs group & $13.52 \pm 2.12$ & $14.53 \pm 1.39$ & $3.26 \pm 0.78$ & $89 \%$ & $10.03 \pm 1.31$ \\
\hline \multicolumn{6}{|c|}{ Post hoc $p$-value } \\
\hline Control vs. $\mathrm{CdCl}_{2}$ & $<0.001 *$ & $<0.001 *$ & $<0.001 *$ & $<0.001 *$ & $<0.001 *$ \\
\hline Control vs. Rs & $0.03 *$ & 0.09 & 0.29 & 0.32 & $<0.001 *$ \\
\hline Control vs. $\mathrm{CdCl}_{2}+\mathrm{Rs}$ & $<0.001 *$ & $<0.001 *$ & $<0.001 *$ & $<0.001 *$ & $<0.001 *$ \\
\hline $\mathrm{CdCl}_{2}$ vs. Rs & $<0.001 *$ & $<0.001 *$ & $<0.001 *$ & $<0.001 *$ & $<0.001 *$ \\
\hline $\mathrm{CdCl}_{2}$ vs. $\mathrm{CdCl}_{2}+\mathrm{Rs}$ & $<0.001 *$ & $<0.001 *$ & $<0.001 *$ & $<0.001 *$ & $<0.001 *$ \\
\hline Rs vs. $\mathrm{CdCl}_{2}+\mathrm{Rs}$ & $<0.001$ * & $<0.001 *$ & $<0.001$ * & $<0.001 *$ & $<0.001 *$ \\
\hline
\end{tabular}

${ }^{*}$ Statistically significant $(p$-value < 0.05). Cd: cadmium; Rs: resveratrol; SOD: superoxide dismutase; CAT: catalase; GPx: glutathione peroxidase; MDA: malondialdehyde; and TAC: total antioxidant capacity. ${ }^{\text {a: }}$ significant difference to control group; ${ }^{\text {b }}$ : significant difference to Rs group.

The same finding was obtained for GPx activity, which declined in the Cd group and was elevated by the Rs treatment after Cd.

Regarding the oxidative damage in the hepatic tissues, Table 2 represents the MDA levels (the final marker of lipid peroxidation). MDA levels were elevated greatly in the DC group as compared to the control group. 


\section{Histopathological Finding}

Histopathological findings showed normal hepatic structure in the control group, $\mathrm{CdCl}_{2}$ induced hepatic damages, microvesicular steatosis hepatocytes with ballooning of hepatocytes and pericellular fibrosis. Meanwhile, the Rs group showed that hepatic tissues showing a central vein surrounded by normal cords of liver cells. While, groups treated with the $\mathrm{CdCl}_{2}$ and $\mathrm{Rs}$ combination showed normal hepatocytes with the beginnings of mild hypertrophy; with the appearance of binucleated hepatocytes shown in Figure 2 and the histological score shown in Table 3.
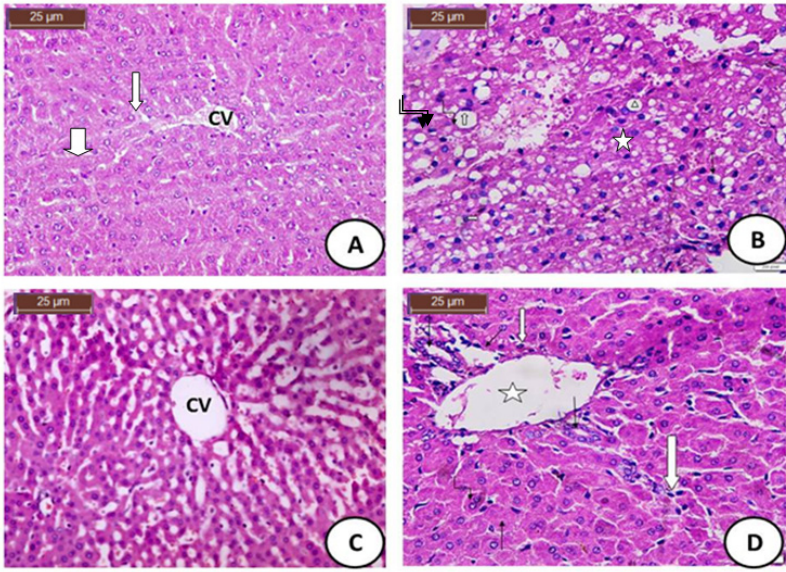

Figure 2. Effect of Cadmium and Resveratrol on hepatic tissues. (A) Control group: Photomicrograph of normal hepatic tissues showing central vein $(\mathrm{CV})$ surrounded by rows and trabeculae of nor-mal liver celld (H\&E $\times 100)$; (B) Cadmium group: Photomicrograph of hepatic tissues treated with cadmium showing showing loss of normal hepatic architecture, macrovesicular ( $($ ) microvesicular steatosis hepatocytes $(\Longrightarrow)$ with ballooning of hepatocytes $(\downarrow)$ and cytoplasmic clearing (signet ring appearance $(\checkmark)$, hepatocellular damage, inflammatory infiltrate and pericellular fibrosis $(\triangle)$. (C) Resveratrol group: Photomicrograph of liver tissues treated with resveratrol showing central vein (CV) surrounded by normal cords of liver cells (H\&E $\times 100)$. (D) Cadmium + Resveratrol group: Photomicrograph of hepatic tissues treated with Cadmium + Resveratrol showing normal hepatocytes with beginning of mild hypertrophy, appearance of binucleated hepatocytes $(\sqrt{ })$, with vesicular nuclei and granular cytoplasmand formation of new bile ductules infiltrated by inflammatory cells $(\stackrel{\downarrow}{\checkmark})$ at the periphery of mildly dilated portal vein (访) With infiltration of blood sinusoids by inflammatory cells (ل) $(\mathrm{H} \& \mathrm{E} \times 100)$.

Table 3. Histopathological score findings in liver of rats treated with cadmium and resveratrol.

\begin{tabular}{|c|c|c|c|c|}
\hline \multirow[t]{2}{*}{ Findings } & \multirow[b]{2}{*}{ Control } & \multicolumn{3}{|c|}{ Groups } \\
\hline & & Cadmium & Resveratrol & Cadmium + Resveratrol \\
\hline Normal hepatic tissues & ++++ & - & ++++ & +++- \\
\hline Normal central vein & ++++ & + & ++++ & +++- \\
\hline Dilated congested central vein & - & ++++ & - & +++- \\
\hline Degenerated liver cells & - & ++++ & - & +++- \\
\hline Fatty change of liver cells & - & ++++ & - & +++- \\
\hline Symbol & \multicolumn{4}{|c|}{ Meaning } \\
\hline $\begin{array}{l}- \\
++++ \\
+++- \\
+++- \\
+-\end{array}$ & \multicolumn{4}{|c|}{$\begin{array}{c}\text { Absence of the change. } \\
\text { A change which was often found. } \\
\text { A change which was observed in almost group. } \\
\text { A change so often not observed in all group. } \\
\text { A change that was rare in the group. }\end{array}$} \\
\hline
\end{tabular}




\section{Discussion}

Excessive exposure to $\mathrm{Cd}$ induced several health problems, mainly as cardiovascular dysfunction and hepatotoxicity [5]. The current study assessed the Cd effects on the liver function markers and the levels of the antioxidant enzymes, such as GPx, CAT and SOD. Histopathological variations were examined mainly in the Hepatic tissues.

Previous studies have mainly and excessively reported the potent antioxidant capacities of Rs. So, we aimed to assess the possible hepatoprotective effects of Rs against Cd hepatotoxicity. The results indicated a main decline in the total protein levels and mainly elevates the hepatic enzymes ALP, LDH, ALT and AST after the successive treatment with Cd.

Hypoproteinemia case was mainly showed in Cd group, which would be due to the dietary insufficiency and/or the high excessive excretion rate Chawla [40]. The observed decline in the total protein levels might be afforded by inflammation of the hepatic tissues as a result of treatment with Cd treatment and alters the biosynthesis of protein [40].

Gaskill et al. [41] reported severe hepatic toxicity reflected by significant elevations in the hepatic enzymes ALT, AST, ALP and GGT in the Cd-treated group as compared with those in the control group, which is in accordance with the results of the current study. The current results are also in accordance with those of Newairy et al. [42], who reported that $\mathrm{Cd}$ treatment elevated oxidative damage markers and that this oxidative stress could be the 1st sign of $\mathrm{Cd}$ for hepatotoxicity incidence.

Confirming the obtained results, Renugadevi and Prabu [23] reported Cd-induced oxidative stress and hepatotoxicity in liver tissues.

Hepatic injury caused by Cd treatment was clearly shown by the elevated levels of hepatic enzymes, concurrent with increased levels of the lipid peroxidation marker. Lakshmi et al. [43] also confirmed the obtained results by revealing that Cd exposure elevated the levels of the hepatic biomarkers and decreased the levels of total proteins.

The administration of $\mathrm{Cd}$ resulted in a significant increment in MDA levels. The current findings are in accordance with the results reported by Alghasham et al. [44], that $\mathrm{Cd}(40 \mathrm{mg})$ markedly elevated the stress marker (MDA) in male rats. Therefore, $\mathrm{Cd}$ is supposed to induce hepatotoxicity, which is associated with the incidence of oxidative stress.

The current results proved that levels of MDA were elevated markedly, Meanwhile the levels of antioxidant enzymes were declined markedly due to $\mathrm{Cd}$ treatment. The free radicals' triggering is the main mechanism of stimulation of the hepatic toxicity by $\mathrm{Cd}$ [45]. Oxidative stress is mainly characterized by the excessive triggering of the free radicals that result in induction of high lipid peroxidation levels and the high damaging of the cellular membranes [46].

Phospholipids of the cellular membrane are mainly oxidized and trigger MDA, which is considered as the main cause of inducing of the oxidative stress [47]. Glutathione is a key co-factor for triggering of the antioxidant enzymes, these antioxidant enzymes prevent the cellular injury from the production of the high levels of free radicals and helps mainly in the toxins removal [48].

There was a severe hepatic injury to the liver in the Cd-treated group. Hepatocytes were mainly observed as hepatic masses. The hepatic tissues were irregular. The hepatocytes have pyknotic nuclei with appearance of large foamy cytoplasm. The present results were in agreement with the previously obtained results, such as the loss in the hepatic architecture and changes in the lipid structures of the hepatic tissues.

Rs administration markedly reduced the cadmium-induced increase in the hepatocellular enzymes and severe hepatic injury, according to AST, ALT and ALP, which are significant markers of hepatic damage, and their serum elevation indicates a loss of cellular membrane integrity [46].

The hepatic enzymes AST, ALT and ALP declined after the administration of Rs, and this proved the improvement of the hepatocytes. AST is a marker of hepatic necrosis. ALT is a hepatic enzyme, which is elevated in the case of hepatic diseases associated with cellular death [49]. ALP is a hepatic enzyme that arises mainly from the bile duct [50]. 
ALP is a significant indicator of cholestasis [51-53]. Obstruction causes fats to be accumulated in the blood instead of being alleviated normally. Rs reduced the AST, ALT and ALP levels, suggesting that Rs can be a good agent for hepatoprotection $[54,55]$.

Additionally, the declined total protein levels in the Cd group suggest a decrease in the protein synthesis level. On the other hand, protein levels were elevated in the Rs-treated group, suggesting hepatic cellular amelioration.

Oxidative stress damages and injuries result in the breakdown of the cellular membrane, which leads to the formation of end products of oxidation, such as MDA [56,57].

Free radicals are generated during $\mathrm{Cd}$ metabolism, have a potent effect on and interact with the triglycerides of the hepatic cellular membranes and can produce lipid peroxides.

The lipid peroxidation is a phenomenon that is common in toxic mechanisms. It occurs under normal physiological conditions [58,59].

The obtained results for the hepatic tissues of the Cd-treated group showed a significant elevation in MDA levels and a significant decline in glutathione levels. MDA is an oxidative stress marker. The significant decline in MDA levels and increment in the glutathione enzyme in Rs-treated animals may reflect a decrease in the lipid peroxidation and increment in the cellular antioxidant defense enzymes. This indicates that Rs reduces the generation of free radicals and thus reduces oxidative stress [52,60-62].

Rs has been proven to possess high antioxidant activity [46]. Animals treated with Rs only showed a normal physiological status, which proves the safety of using Rs. Rs induced a cellular restoration effect on the hepatic tissues [47,63].

The histological parameters were implemented for the evaluation of liver tissue damage. The necrosis in the $\mathrm{Cd}$ group indicated the death of the hepatic cells. The fatty change in the liver noticed in the $\mathrm{Cd}$ group reflects an imbalance of lipid metabolism due to the hepatic tissues.

\section{Conclusions}

Resveratrol has an enhancing effect on hepatotoxicity induced by cadmium. The obtained results indicate that the decline in antioxidant status contributes to cadmium toxicity, especially in the hepatic tissues. The significant increase observed in the reactive oxygen species in the hepatic tissues confirmed the occurrence of oxidative stress due to cadmium exposure; thus, the hepatic tissues are subjected to a high level of oxidative stress. Histological amelioration was observed after the administration of resveratrol to the cadmium-treated group. Resveratrol treatment removed the triggered free radicals induced by $\mathrm{Cd}$.

Author Contributions: Conceptualization and methodology, N.M.A.-B., R.Z.H.; software, N.M.A.-B., R.Z.H.; validation, N.M.A.-B., R.Z.H.; formal analysis and investigation, N.M.A.-B., R.Z.H.; resources, N.M.A.-B., R.Z.H.; data curation, N.M.A.-B., R.Z.H.; writing-original draft preparation, N.M.A.-B., R.Z.H.; writing-review and editing, N.M.A.-B., R.Z.H.; visualization and funding acquisition, N.M.A.-B., R.Z.H. All authors have read and agreed to the published version of the manuscript.

Funding: The publication funding was achieved by the Deanship of Scientific Research (DSR), King Abdulaziz University, Jeddah, Saudi Arabia.

Institutional Review Board Statement: The experimental work was approved by the approval of ethical committee of Deanship of scientific research in Taif University under approval number: 39-31-0034.

Informed Consent Statement: Not applicable.

Data Availability Statement: Data available upon demand from the corresponding author.

Acknowledgments: The authors acknowledge the Taif University Researchers supporting number (TURSP-2020/21), Taif University, Taif, Saudi Arabia.

Conflicts of Interest: The authors declare no conflict of interest. 


\section{References}

1. Flora, S.J.S.; Behari, J.R.; Ashquin, M.; Tandon, S.K. Time-dependent protective effect of selenium against cadmium-induced nephrotoxicity and hepatotoxicity. Chem. Biol. Interact. 1982, 42, 345-351. [CrossRef]

2. Giuseppe, G.; Maria, S.S.; Graziantonio, L.; Alessia, C.; Alessia, C. The Effects of Cadmium Toxicity. Int. J. Environ. Res. Public Health 2020, 17, 3782.

3. Thévenod, F. Nephrotoxicity and the Proximal Tubule. Nephron 2003, 93, 87-93. [CrossRef]

4. Fukumoto, M.; Kujiraoka, T.; Hara, M.; Shibasaki, T.; Hosoya, T.; Yoshida, M. Effect of cadmium on gap junctional intercellular communication in primary cultures of rat renal proximal tubular cells. Life Sci. 2001, 69, 247-254. [CrossRef]

5. Abu-El-Zahab, H.S.H.; Hamza, R.Z.; Montaser, M.M.; El-Mahdi, M.M.; Al-Harthi, W.A. Antioxidant, antiapoptotic, antigenotoxic, and hepatic ameliorative effects of L-carnitine and selenium on cadmium-induced hepatotoxicity and alterations in liver cell structure in male mice. Ecotoxicol. Environ. Saf. 2019, 173, 419-428. [CrossRef] [PubMed]

6. Rani, A.; Kumar, A.; Lal, A.; Pant, M. Cellular mechanisms of cadmium-induced toxicity: A review. Int. J. Environ. Health Res. 2014, 24, 378-399. [CrossRef] [PubMed]

7. Alharthi, W.A.; Hamza, R.Z.; Elmahdi, M.M.; Abuelzahab, H.S.H.; Saleh, H. Selenium and L-Carnitine Ameliorate Reproductive Toxicity Induced by Cadmium in Male Mice. Biol. Trace Element Res. 2019, 197, 619-627. [CrossRef]

8. Refat, M.S.; Hamza, R.Z.; Adam, A.M.A.; Saad, H.A.; Gobouri, A.A.; Al-Harbi, F.S.; Al-Salmi, F.A.; Altalhi, T.; El-Megharbel, S.M. Quercetin/Zinc complex and stem cells: A new drug therapy to ameliorate glycometabolic control and pulmonary dysfunction in diabetes mellitus: Structural characterization and genetic studies. PLoS ONE 2021, 16, e0246265. [CrossRef] [PubMed]

9. Mokni, M.; Elkahoui, S.; Limam, F.; Amri, M.; Aouani, E. Effect of Resveratrol on Antioxidant Enzyme Activities in the Brain of Healthy Rat. Neurochem. Res. 2007, 32, 981-987. [CrossRef]

10. Wang, P.; Sachar, M.; Lu, J.; Shehu, A.I.; Zhu, J.; Chen, J.; Ma, X. The essential role of the transporter ABCG2 in the pathophysiology of erythropoietic protoporphyria. Sci. Adv. 2019, 5, eaaw6127. [CrossRef]

11. Dalaklioglu, S.; Genc, G.E.; Aksoy, N.H.; Akcit, F.; Gumuslu, S. Resveratrol ameliorates methotrexate-induced hepatotoxicity in rats via inhibition of lipid peroxidation. Hum. Exp. Toxicol. 2013, 32, 662-667. [CrossRef] [PubMed]

12. Leonard, S.S.; Xia, C.; Jiang, B.-H.; Stinefelt, B.; Klandorf, H.; Harris, G.K.; Shi, X. Resveratrol scavenges reactive oxygen species and effects radical-induced cellular responses. Biochem. Biophys. Res. Commun. 2003, 309, 1017-1026. [CrossRef] [PubMed]

13. Tian, B.; Liu, J. Resveratrol: A review of plant sources, synthesis, stability, modification and food application. J. Sci. Food Agric. 2020, 100, 1392-1404. [CrossRef] [PubMed]

14. de Moraes, A.C.N.; de Andrade, C.B.V.; Ramos, I.P.R.; Dias, M.L.; Batista, C.M.P.; Pimentel, C.F.; de Carvalho, J.J.; Goldenberg, R.C.D.S. Resveratrol promotes liver regeneration in drug-induced liver disease in mice. Food Res. Int. 2021, 142, 110185. [CrossRef] [PubMed]

15. Liu, X. ABC Family Transporters. In Advances in Experimental Medicine and Biology; Springer: Berlin/Heidelberg, Germany, 2019; Volume 1141, pp. 13-100.

16. Sener, G.; Toklu, H.Z.; Sehirli, A.O.; Velioğlu-Öğünç, A.; Cetinel, S.; Gedik, N. Protective effects of resveratrol against acetaminophen-induced toxicity in mice. Hepatol. Res. 2006, 35, 62-68. [CrossRef]

17. Subramanya, S.B.; Venkataraman, B.; Meeran, M.F.N.; Goyal, S.N.; Patil, C.R.; Ojha, S. Therapeutic Potential of Plants and Plant Derived Phytochemicals against Acetaminophen-Induced Liver Injury. Int. J. Mol. Sci. 2018, 19, 3776. [CrossRef]

18. Abdu, S.B.; Al-Bogami, F.M. Influence of resveratrol on liver fibrosis induced by dimethylnitrosamine in male rats. Saudi J. Biol. Sci. 2019, 26, 201-209. [CrossRef]

19. Ungvari, Z.; Bagi, Z.; Feher, A.; Recchia, F.A.; Sonntag, W.E.; Pearson, K.; De Cabo, R.; Csiszar, A. Resveratrol confers endothelial protection via activation of the antioxidant transcription factor Nrf2. Am. J. Physiol. Circ. Physiol. 2010, 299, H18-H24. [CrossRef]

20. Esterbauer, H.; Cheeseman, K.H. Determination of aldehydic lipid peroxidation products: Malonaldehyde and 4-hydroxynonenal. Regul. Cell Death Part A Apoptotic Mech. 1990, 186, 407-421. [CrossRef]

21. Rubiolo, J.A.; Mithieux, G.; Vega, F.V. Resveratrol protects primary rat hepatocytes against oxidative stress damage: Activation of the Nrf2 transcription factor and augmented activities of antioxidant enzymes. Eur. J. Pharmacol. 2008, 591, 66-72. [CrossRef]

22. El-Agamy, D.S. Comparative effects of curcumin and resveratrol on aflatoxin B1-induced liver injury in rats. Arch. Toxicol. 2010, 84, 389-396. [CrossRef] [PubMed]

23. Renugadevi, J.; Prabu, S.M. Cadmium-induced hepatotoxicity in rats and the protective effect of naringenin. Exp. Toxicol. Pathol. 2010, 62, 171-181. [CrossRef] [PubMed]

24. Oktem, G.; Uysal, A.; Oral, O.; Sezer, E.D.; Olukman, M.; Erol, A. Resveratrol attenuatesdoxorubicin-induced cellular damage by modulating nitric oxide and apoptosis. Exp. Toxicol. Pathol. 2012, 64, 471-479. [CrossRef] [PubMed]

25. Boussarie, D. Hématologie des rongeurs et lagomorphes de compagnie. Bull. Acad. Vét. France 1999, 72, 209-216. [CrossRef]

26. Reitman, S.; Frankel, S.A. colorimetric method for the determination of serum glutamic oxyacetic and glutamic pyruvic transaminases. Am. J. Clin. Pathol. 1957, 28, 56-63. [CrossRef]

27. Young, D.C.; Koon, H.R.; Hyung, K.C. In vitro and in vivo experimental effect of Korean red ginseng on erection. J. Urol. 1999, 162, $1508-1511$.

28. Orlowski, M.; Meister, A. Isolation of gamma-glutamyl transpeptidase from hog kidney. J. Biol. Chem. 1965, $240,338-347$. [CrossRef] 
29. Bowers, L.D.; Wong, E.T. Kinetic serum creatinine assays. II. A critical valuation and review. Clin. Chem. 1980, $26,555-561$. [CrossRef]

30. Bradford, M.M. A Rapid and Sensitive Method for the Quantitation of Microgram Quantities of Protein Utilizing the Principle of Protein-Dye Binding. Anal. Biochem. 1976, 72, 248-254. [CrossRef]

31. Carr, T.; Andressen, C.J.; Rudel, L.L. Enzymatic determination of triglyceride, free cholesterol and total cholesterol in tissue lipid extracts. Clin. Chem. 1993, 26, 39-42.

32. Warnick, G.R.; Benderson, J.; Albers, J.J. Selected methods of clinical chemistry. Am. Assoc. Clin. Chem. 1983, 10, 91-99.

33. Friedewald, W.T. Estimation of concentration of low-density lipoprotein cholesterol in plasma without use of the preparative ultracentrifuge. Clin. Chem. 1972, 18, 499-502. [CrossRef]

34. Marklund, S.; Marklund, G. Involvement of the superoxide anion radical in the autoxidation of pyrogallol and a convenient assay for superoxide dismutase. Eur. J. Biochem. 1974, 47, 469-474. [CrossRef] [PubMed]

35. Aebi, D.J. Glucose-6-phosphate dehydrogenase. In Methodsof Enzymatic Analysis, 2nd ed.; Bergmeyer, H.U., Ed.; VCH Verlagsgesellschaft mbH: Weinheim, Germany, 1986; pp. 190-196.

36. Hamza, R.Z.; Al-Motaan, S.E.; Malik, N. Protective and Antioxidant Role of Selenium Nanoparticles and Vitamin C against Acrylamide Induced Hepatotoxicity in Male Mice. Int. J. Pharmacol. 2019, 15, 664-674. [CrossRef]

37. Prieto, P.; Pineda, M.; Aguilar, M. Spectrophotometric Quantitation of Antioxidant Capacity through the Formation of a Phosphomolybdenum Complex: Specific Application to the Determination of Vitamin E. Anal. Biochem. 1999, 269, 337-341. [CrossRef]

38. Gabe, M. Techniques Histologiques Histological Techniques; Masson Publisher: Paris, French, 1968.

39. Martynov, A.; Sushama, L.; Laprise, R. Simulation of temperate freezing lakes by one-dimensional lake models: Performance assessment for interactive coupling with regional climate models. Boreal Environ. Res. 2010, 15, 143-164. [CrossRef]

40. Chawla, R. Practical Clinical Biochemistry: Methods and Interpretations, 4th ed.; JP Medical Ltd.: New Delhi, India, 2014.

41. Gaskill, C.L.; Miller, L.M.; Mattoon, J.S.; Hoffmann, W.E.; Burton, S.A.; Gelens, H.C.J.; Ihle, S.L.; Miller, J.B.; Shaw, D.H.; Cribb, A.E. Liver Histopathology and Liver and Serum Alanine Aminotransferase and Alkaline Phosphatase Activities in Epileptic Dogs Receiving Phenobarbital. Veter Pathol. 2005, 42, 147-160. [CrossRef]

42. Al-Harbi, M.S.; Hamza, R.Z. Potential Ameliorative Effects of Selenium and Chromium Supplementation against Toxicity and Oxidative Stress in Streptozotocin Diabetic Rats. Int. J. Pharm. 2016, 12, 483-495.

43. Lakshmi, G.D.; Kumar, P.R.; Bharavi, K.; Annapurna, P.; Rajendar, B.; Patel, P.T.; Kumar, C.S.V.S.; Rao, G.S. Protective effect of Tribulus terrestris linn on liver and kidney in cadmium intoxicated rats. Indian J. Exp. Boil. 2012, 50, 141-146.

44. Alghasham, A.; Tarek, A.S.; Abdel-Raheim, M.M. Effect of cadmium-polluted water on plasma levels of tumor necrosis factor- $\alpha$, interleukin-6 and oxidative status biomarkers in rats: Protective effect of curcumin. Food Chem. Toxicol. 2013, 59, 160-164. [CrossRef]

45. Mecdad, A.A.; Ahmed, M.H.; ElHalwagy, M.E.; Afify, M.M. A study on oxidative stress biomarkers and immunomodulatory effects of pesticides in pesticide-sprayers. Egypt. J. Forensic Sci. 2011, 2, 93-98. [CrossRef]

46. Hamza, R.Z.; El-Shenawy, N.S. Anti-inflammatory and antioxidant role of resveratrol on nicotine-induced lung changes in male rats. Toxicol. Rep. 2017, 4, 399-407. [CrossRef]

47. Al-Baqami, N.; Hamza, R. Synergistic antioxidant capacities of vanillin and chitosan nanoparticles against reactive oxygen species, hepatotoxicity, and genotoxicity induced by aging in male Wistar rats. Hum. Exp. Toxicol. 2021, 40, 183-202. [CrossRef] [PubMed]

48. Al-Hazmi, M.A.; Rawi, S.M.; Hamza, R.Z. Biochemical, histological, and neuro-physiological effects of long-term aluminum chloride exposure in rats. Metab. Brain Disease 2021, 36, 36429-36436. [CrossRef]

49. Hamza, R.Z.; EL-Megharbel, S.M.; Altalhi, T.; Gobouri, A.A.; Alrogi, A.A. Hypolipidemic and hepatoprotective synergistic effects of selenium nanoparticles and vitamin. E against acrylamide induced hepatic alterations in male albino mice. Appl. Organomet. Chem. 2020, 34, e5458. [CrossRef]

50. Hamza, R.Z.; Al-Salmi, F.A.; El-Shenawy, N.S. Evaluation of the effects of the green nanoparticles zinc oxide on monosodium glutamate-induced toxicity in the brain of rats. PeerJ 2019, 7, e7460. [CrossRef]

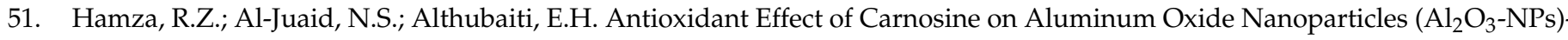
induced Hepatotoxicity and Testicular Structure Alterations in Male Rats. Int. J. Pharmacol. 2018, 14, 740-750. [CrossRef]

52. Rafati, A.; Hoseini, L.; Babai, A.; Noorafshan, A.; Haghbin, H.; Karbalay-Doust, S. Mitigating Effect of Resveratrol on the Structural Changes of Mice Liver and Kidney Induced by Cadmium: A Stereological Study. Prev. Nutr. Food Sci. 2015, 20, 266-275. [CrossRef]

53. Hamza, R.Z.; Diab, A.A.A.; Zahra, M.H.; Asalah, A.K.; Attia, M.S.; Moursi, S.M. Ameliorative effect of apelin-13 against renal complications in L-NAME-induced preeclampsia in rats. PeerJ 2021, 9, e11110. [CrossRef]

54. Fan, G.; Tang, J.J.; Bhadauria, M.; Nirala, S.K.; Dai, F.; Zhou, B.; Li, Y.; Liu, Z.L. Resveratrol ameliorates carbon tetrachlorideinduced acute liver injury in mice. Environ. Toxicol. Pharmacol. 2009, 28, 350-356. [CrossRef]

55. Hamza, R.Z.; Al-Salmi, F.A.; Laban, H.; El-Shenawy, N.S. Ameliorative Role of Green Tea and Zinc Oxide Nanoparticles Complex Against Monosodium Glutamate-Induced Testicular Toxicity in Male Rats. Curr. Pharm. Biotechnol. 2020, 21, 488-501. [CrossRef]

56. El-Shenawy, N.S.; AL-Harbi, M.S.; Hamza, R.Z. Effect of vitamin E and selenium separately and in combination on biochemical, immunological and histological changes induced by sodium azide in male mice. Exp. Toxicol. Pathol. 2014, 67, 65-76. [CrossRef] [PubMed] 
57. Reham, Z.; Hamza, F.; Al-Salmi, A.; El-Shenawy, N.S. Chitosan and Lecithin Ameliorate Osteoarthritis Symptoms Induced by Monoiodoacetate in a Rat Model. Molecules 2021, 25, 5738.

58. Hamza, R.Z.; Al-Harbi, M.S.; Al-Hazaa, M.A. Neurological Alterations and Testicular Damages in Aging Induced by D-Galactose and Neuro and Testicular Protective Effects of Combinations of Chitosan Nanoparticles, Resveratrol and Quer-cetin in Male Mice. Coatings 2021, 11, 435. [CrossRef]

59. AlBasher, G.; Abdel-Daim, M.M.; Almeer, R.; Ibrahim, K.A.; Hamza, R.Z.; Bungau, S.; Aleya, L. Synergistic antioxidant effects of resveratrol and curcumin against fiproniltriggered oxidative damage in male albino rats. Environ. Sci. Pollut. Res. 2020, 27, 6505-6514. [CrossRef]

60. Refat, M.S.; Hamza, R.Z.; Adam, A.A.; Saad, H.A.; Gobouri, A.A.; Al-Salmi, F.A.; Altalhi, T.A.; El-Megharbel, S.M. Potential Therapeutic Effects of New Ruthenium (III) Complex with Quercetin: Characterization, Structure, Gene Regulation, and Antitumor and Anti-Inflammatory Studies (RuIII/Q Novel Complex Is a Potent Immunoprotective Agent). Crystals 2021, 11, 367. [CrossRef]

61. Eybl, V.; Kotyzova, D.; Koutensky, J. Comparative study of natural antioxidants-Curcumin, resveratrol and melatoninIn cadmium-induced oxidative damage in mice. Toxicology 2006, 225, 150-156. [CrossRef]

62. Moamen, S.; Refat, R.Z.; Hamza, A.A.; Adam, H.A.; Saad, A.A.; Gobouri, E.A.; Fawziah, A.; Tariq, A.; Altalhi, E.K.; Ahmed, G.; et al. Antioxidant, Antigenotoxic, and Hepatic Ameliorative Effects of Quercetin/Zinc Complex on Cadmium-Induced Hepatotoxicity and Alterations in Hepatic Tissue Structure. Coatings 2021, 11, 501.

63. Cheng, K.; Yan, E.; Song, Z.; Li, S.; Zhang, H.; Zhang, L.; Wang, C.; Wang, T. Protective effect of resveratrol against hepatic damage induced by heat stress in a rat model is associated with the regulation of oxidative stress and inflammation. J. Therm. Biol. 2019, 82, 70-75. [CrossRef] 